\title{
Audio-magnetotelluric investigation of sulfide mineralization in Proterozoic-Archean greenstone belts of Eastern Indian Craton
}

\author{
Shailendra Singh ${ }^{1}$, Ved P Maurya ${ }^{1}$, Roshan K Singh ${ }^{1}$, Shalivahan Srivastava ${ }^{1, *}$, \\ AnURAG TrIPATHI ${ }^{1}$ and $\mathrm{P}$ K ADHIKARI ${ }^{2}$ \\ ${ }^{1}$ Department of Applied Geophysics, Centre of Advanced Study, Indian School of Mines, \\ Dhanbad 826004 , India. \\ ${ }^{2}$ Uranium Corporation of India Ltd., Narwapahar, Jharkhand, India. \\ *Corresponding author. e-mail: svismagp@gmail.com
}

MS received 17 January 2017; revised 13 August 2017; accepted 15 August 2017; published online 27 March 2018

Greenstone belts are well known for gold occurrences at different regions of the world. The Dhanjori basin in the eastern Singhbhum region shows major characteristics of a rifted greenstone belt. Initially, we conducted 14 audio-magnetotelluric (AMT) measurements for a profile of $\sim 20 \mathrm{~km}$ in the frequency range of $1 \mathrm{kHz}$ to $10 \mathrm{~Hz}$ over this rather complex geologic environment covering Dhanjori Volcanics (DhV) and Kolhan Group (KG). Subsequently, gravity and magnetic surveys were also conducted over this AMT profile. The purpose of the survey was to identify and map conductive features and to relate them to metallogeny of the area along with the mapping of the basement of Dhanjori basin. The strike analysis showed $\mathrm{N} 30^{\circ} \mathrm{W}$ strike for $\mathrm{DhV}$ for all the frequencies and for sites over $\mathrm{KG}$ domain in the frequency range of $100-10 \mathrm{~Hz}$, but for $\mathrm{KG}$ domain, the obtained strike in $1 \mathrm{kHz}$ to $100 \mathrm{~Hz}$ is $\mathrm{N} 45^{\circ} \mathrm{E}$. As the combination of transverse electric (TE), transverse magnetic (TM) and tipper (Tzy) can recover the electrical signature in complex geological environment, we discuss the conductivity model obtained from TE+TM+Tzy only. The inversion was carried for the regional profile with 14 sites and for 7 sites over KG domain. Conductivity model shows two well resolved conductors, one each in KG and Quartz Pebble Conglomerate Dhanjori (QPCD) domains respectively showing common linked concordant features between these regional and KG profiles. The conductors are interpreted as sulfide mineralization linked with QPCD group of rocks which may host gold. These conductors are also horizontally disposed due to the intrusive younger Mayurbhanj Granite. These intrusives correlate well with the gravity modeling as well. The thickness of the Dhanjori basin at the central is about $3.0 \mathrm{~km}$, similar to that from gravity modeling. The conductivity model also indicates the presence of shallow conductors, but could not be resolved due to lack of high frequency data. However, the results from the close-by drill site indicate the presence of shallow sulfide mineralization hosting gold. The deep level conductors delineated from AMT studies are associated with gravity high and low magnetic. ICP-AES results of Dhanjori samples show significant concentration of gold $\sim 5.0 \mathrm{~g} / \mathrm{t}$, which is of economic consideration. Thus, it can be inferred that the conductors have evidences of sulfide mineralization which host gold.

Keywords. Dhanjori volcanics; greenstone belts; audio-magnetotelluric; conductors. 


\section{Introduction}

The Eastern Indian Craton (EIC) is mainly characterized by the Archean nucleus of Singhbhum Granite (SG) batholithic complex and ancient supracrustals surrounded by several elongate and arcuate Proterozoic belts (Saha 1994). There are two major volcanic dominant belts occurring along or close to the southern margin (Dhanjori Volcanics, DhV) and the other extending along the northern margin (Dalma Volcanics). DhV are one of the five large early Proterozoic mafic volcanic suites of the Singhbhum Craton (Saha 1994). The Singhbhum Shear Zone (SSZ) northeast of DhV separates it from the Singhbhum group of formation (figure 1). The shear zone mylonites comprise deformed amygdaloidal meta-volcanics of the Dhanjori Formation (Das et al. 2008). It is believed that the Dhanjori meta-volcanics and its variant group are the source of the sulfides in the area which were later remobilized and deposited along the SSZ as an epigenetic deposit (Das et al. 2008).

Greenstone belts are metamorphosed volcanosedimentary sequences occurring within the cratons of Archean and Proterozoic in granitic and gneissic rocks (De Wit et al. 1997). The belts often have ore deposits of economic minerals like gold, silver, copper, zinc, nickel and lead (Pirajno 2007). Komatiites and komatiitic basalts are characteristics of both Archean greenstone belt (Sproule et al. 2002 and others) and Proterozoic volcano-sedimentary succession (Zhou et al. 2002 and others). Groves et al. (1987) explained the evolution of greenstone belts associated with gold deposits either by metamorphic model or by rift phase model. Most of the well-known gold deposits occur mainly within the Archean greenstone belts (Groves et al. 1987). Kolar Gold Field, India; Barberton, South Africa; Yilgarn craton, Australia and Abitibi greenstone belt, Canada are the well-known examples of greenstone belts related to most of the gold mineralization distribution all over the world. There are hundreds of small uneconomic deposits, with only a few large to giant ore bodies reported in Canadian (Dubé and Gosselin 2007; Percival 2007), Western Australian Shields (Groves et al. 1987; Wyche et al. 2012), Kaapvaal (Anhaeusser 1976; Kirk et al. 2002) and Rhodesian (Foster 1985) cratons. These cratons carry a geographic and temporal clustering of large gold deposits within the greenstone belts (Goldfarb et al. 2001).

The most studied greenstone belts in India are located within the Dharwar Craton in the southern peninsular India (Das et al. 1990). These are Chitradurga greenstone belts, part of Western Dharwar; Sargur group Nagamangala greenstone belts, part of Western Dharwar; and Kadiri greenstone belts, part of Eastern Dharwar Supergroup (Jayananda et al. 2013). The other important greenstone schist belt of $\mathrm{DhV}$ enriched with gold $(\mathrm{Au})$ and other mineralization is located in the Singhbhum Craton of the Eastern India (Mazumder 2005). Kundarkocha gold deposit $\left(22^{\circ} 10^{\prime} \mathrm{N}, 86^{\circ} 16^{\prime} \mathrm{E}\right)$ has proven evidences of gold mineralization within the Precambrian Singhbhum orogenic belt in the Eastern India (Sahoo and Venkatesh 2014). Recently, Jha et al. (2015) reported the occurrence of invisible gold within the North Singhbhum Mobile Belt of Singhbhum crustal province by petrographic, SEM and EPMA studies. Maurya et al. (2015) reported evidences of $\mathrm{Au}-\mathrm{VMS}$ in the northern fringe of Dalma Volcanics using Magnetotelluric/Audio magnetotelluric (MT/AMT) studies. Geological studies supported by geochemical results clearly established gold mineralization to be mainly associated with the quartz-pebble conglomerates (QPC) in Dhanjori basin (Haque and Dutta 1996).

AMT is a natural source electromagnetic technique used for mapping shallow subsurface electrical conductivity distributions. In general, greenstone belts have various litho-types of significantly differing resistivity (Zhang et al. 1995). AMT surveys over greenstone belts can provide a good insight underneath it and can also be used to detect any near-surface electrically conductive structures or lateral contrasts in conductivity (Zhang et al. 1995). MT/AMT surveys have been conducted over several mineral occurrences of the world (Livelybrooks et al. 1996; Meju 2002; Jones and Garcia 2003; Heinson et al. 2006; Tuncer et al. 2006; Queralt et al. 2007).

Yamaguchi et al. (2010) carried out an AMT survey across Yamasaki fault system in Japan and identified conductors linked with clay minerals and a fluid network within a fault-related fracture zone. Craven et al. (2013) conducted an MT survey over an iron oxide copper-gold NICO deposits in northwest territories of Canada to understand deep-seated conduits existed beneath it. Heinson et al. (2006) had shown MT evidences for a deep crustal mineralizing system over a well-known iron oxide copper-gold Olympic Dam deposit, situated along the margin of the Proterozoic Gawler craton, south Australia. They mapped mineralization system fluid pathways also constrained by crustal 


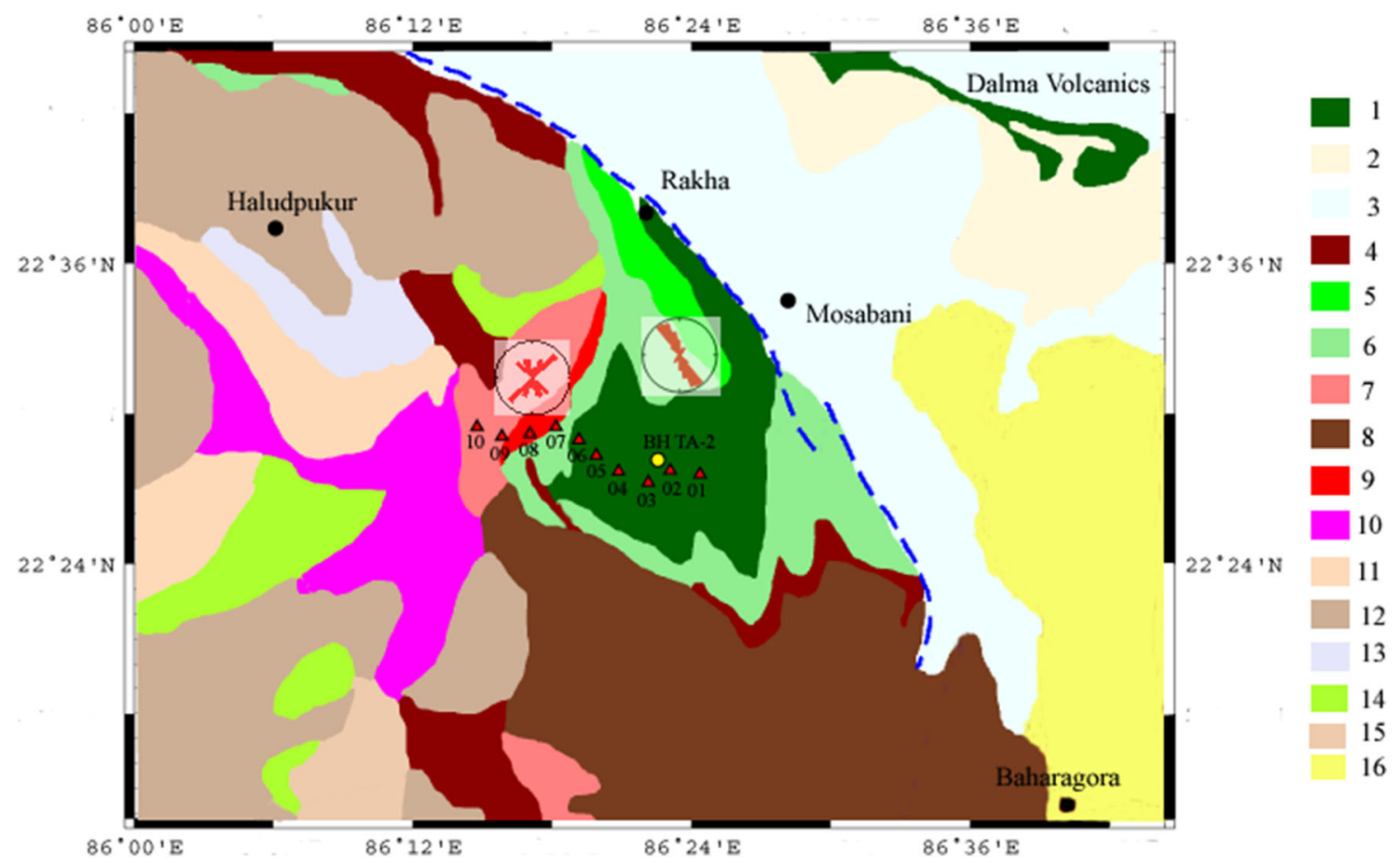

Figure 1. Geological map with 14 AMT soundings (shown by black triangle) with a borehole BH TA-2 (shown by yellow circle) in between AMT site DH-02 and DH-03. Rose diagrams for phase sensitive strike (PSS) for DhV and KG-PGAU group of rocks. 1. Dhanjori Volcanics (DhV); 2. Singhbhum Group Quartzites-pelites; 3. Singhbhum Group pelites, psammipelites; 4. Iron Ore Group shales, tuffs, phyllites; 5. Dhanjori Group (unclassified); 6. Quartzite-Conglomerate-Pelite of Dhanjori (QCPD) group; 7. Proterozoic Gabbro-Anorthosite-Ultramafics (PGAU); 8. Mayurbanj Granite; 9. Kolhan Group (KG); 10. Iron Ore Group lavas, ultramafics; 11. Singhbhum Granite - Phase I; 12. Singhbhum Granite - Phase III; 13. Older Metamorphic Group; 14. Older metamorphic tonalite-gneiss; 15. Singhbhum Granite - Phase II; 16. Alluvium, Tertiaries (after Saha 1994).

structures delineated through deep seismic and magnetotelluric data.

Koziar and Strangway (1978) for the first time carried out AMT soundings over a greenstone belt of the Superior Province of the Precambrian Shield in northwestern Ontario, Canada. They observed very high resistivity over gneissic rocks and granitic intrusives and lower resistivity over the greenstone belts. Zhang et al. (1995) analysed AMT data over northern Abitibi greenstone belt in Quebec, Canada for defining the near-surface geoelectric structures and for imaging major faults and shear zones. Their results suggested the presence of a thin overburden with both conductive and resistive blocks overlying a very resistive basement below the Abitibi greenstone belt.

Geophysical studies (viz., gravity, magnetic, electrical, self-potential (SP) and radiometric, etc.) in the SSZ delineated several mineral deposits (Kailasam 1975; Verma et al. 1984; Das and Agrawal 2001; Sengupta et al. 2001; Anand and Rajaram 2006) with assemblages of $\mathrm{Cu}, \mathrm{Au}$, and U-mineralization. Induced polarization, resistivity, ground magnetic and SP surveys have been carried by both Geological Survey of India (GSI) and Atomic Minerals Directorate for Exploration and Research (AMDER) for concealed uranium and rare-earth metals in SSZ. AMDER also carried out several airborne gamma-ray and radiometric surveys for uranium and rare-earth metals over possible carbonatite-alkaline rock complexes (Krishnamurthy et al. 2004). Unfortunately, until today only geophysical survey, i.e., one deep resistivity sounding using dipole-dipole array and three deep resistivity profile has been carried over the DhV (Das et al. 2008) for locating the possible mineral potential of the $\mathrm{DhV}$.

Reconnaissance gravity, magnetic and audiomagnetotelluric surveys were carried out to understand the structural disposition, nature, depth and the metallogenic potential of the Dhanjori greenstone belt.

\section{Geological setting of the area}

The Dhanjori Formation is located in the eastern part of the Singhbhum Craton (figure 1) and 
Table 1. Generalized stratigraphy of Dhanjori basin (after Acharya et al. 2010).

\begin{tabular}{|c|c|c|}
\hline \multirow[t]{7}{*}{ Dhanjori Group } & Upper & $\begin{array}{l}\text { Tholeiitic basalt (locally pillowed), mafic-ultramafic } \\
\text { tuffs and intrusives, tuffaceous sediments }\end{array}$ \\
\hline & Lower & $\begin{array}{l}\text { Quartzite (locally arkosic) with discontinuous } \\
\text { polymictic conglomerate, interlayered with tuffs }\end{array}$ \\
\hline & Non-conformity & Disconformity \\
\hline & Mayurbhanj Granite & \\
\hline & Phuljhari Formation & $\begin{array}{l}\text { Ultramafic-mafic intrusives, purple and greenish } \\
\text { phyllite, gritty and pebbly shale, acid-mafic } \\
\text { tuff-tuffite, volcanics, Quartzite with lenses of QPC }\end{array}$ \\
\hline & Non-conformity & \\
\hline & Singhbhum Granite & \\
\hline
\end{tabular}

covers an $\sim 800 \mathrm{~km}^{2}$ area (Saha 1994). The age of the Dhanjori Group is broadly varying from 2.6 to 2.1 Gyr (Acharya et al. 2010). It is composed of silici-clastic sedimentary rocks inter-layered with mafic to ultramafic and rare acidic volcanic and volcani-clastic rocks deformed and metamorphosed to lower green-schistfacies (Dunn and Dey 1942 and references therein). The central part of the DhV is $\sim 1.25 \mathrm{~km}$ thick and moving away from center, it progressively becomes thinner and ultimately pinches out (Mazumder and Sarkar 2004). The Dhanjori-Chaibasa succession preserves a normal stratigraphic order and the Dhanjori Formation is therefore older. The Dhanjori Formation directly overlies the Singhbhum Granite and is, in turn, overlain by mica-schist-quartzite assemblages of the Chaibasa Formation. The contact between the two formations, defined by a conglomerate, has been interpreted as an unconformity contact (Mazumder and Sarkar 2004; Mazumder 2005). The Dhanjori basin is flanked by the SSZ to its northern and eastern sides and by the Iron Ore group of rocks in the northwest. The Dhanjori Formation is made up of upper member that comprises volcanics and volcani-clastic rocks along with some quartzites and phyllites and lower member that comprises phyllites, quartzites and thin conglomerates (Mazumder and Sarkar 2004). Acharya et al. (2010) revised the stratigraphy of the Dhanjori basin (table 1).

\section{AMT, gravity and magnetic surveys}

Fourteen AMT soundings were acquired in the frequency range of $1 \mathrm{kHz}$ to $10 \mathrm{~Hz}$. AMT soundings were acquired for a profile length $\sim 20 \mathrm{~km}$ crossing all major lithologies of the Dhanjori Group (figure 1). The AMT sites, DH-01-06 and DH-06' are over DhV; DH-07 and DH-07' are over Quartzite-Conglomerate-Pelites of Dhanjori (QCPD) Group; DH-08 and DH-08' are over Kolhan Group (KG), DH-09; and 09' and 10 are over Proterozoic Gabbro-Anorthosite-Ultramafics (PGAU) (figure 1). The time series for all five components were collected for $6 \mathrm{hr}$ at each site using MTU-5A equipment from Phoenix Geophysics Ltd. $\mathrm{Pb}-\mathrm{PbCl}_{2}$ electrodes were used for acquiring the electric field while the magnetic fields were measured using induction coils. The length of the electrical dipole was $\sim 100 \mathrm{~m}$. AMT data was processed using the extra-hybrid approach by Shalivahan Sinharay and Bhattacharya (2006) in the frequency range of $1 \mathrm{kHz}$ to $10 \mathrm{~Hz}$. Figure 2 shows the data in unrotated coordinate system for some of the representative sites. The processed data is of good quality as the error bars are small and also the scatter is low in this frequency range (figure 2).

We also acquired gravity and magnetic data along a profile coincident with AMT profile at a station spacing of $\sim 500 \mathrm{~m}$. Gravity measurements were carried out using CG-5 gravimeter. Magnetic measurements were carried out using proton precession magnetometer. The base station was re-occupied at every $2 \mathrm{hr}$ for both gravity and magnetic measurements. The acquired gravity data was reduced by applying drift correction and combined elevation correction including both free air and Bouguer correction. The latitude correction for gravity and normal correction for magnetic data were not applied as the study area is $20 \mathrm{~km}$ only. Also, the terrain correction for gravity data was ignored as the elevation of the study area varied within $\sim 50 \mathrm{~m}$. Diurnal correction was only applied to the acquired magnetic data. The combined elevation correction was applied by using 

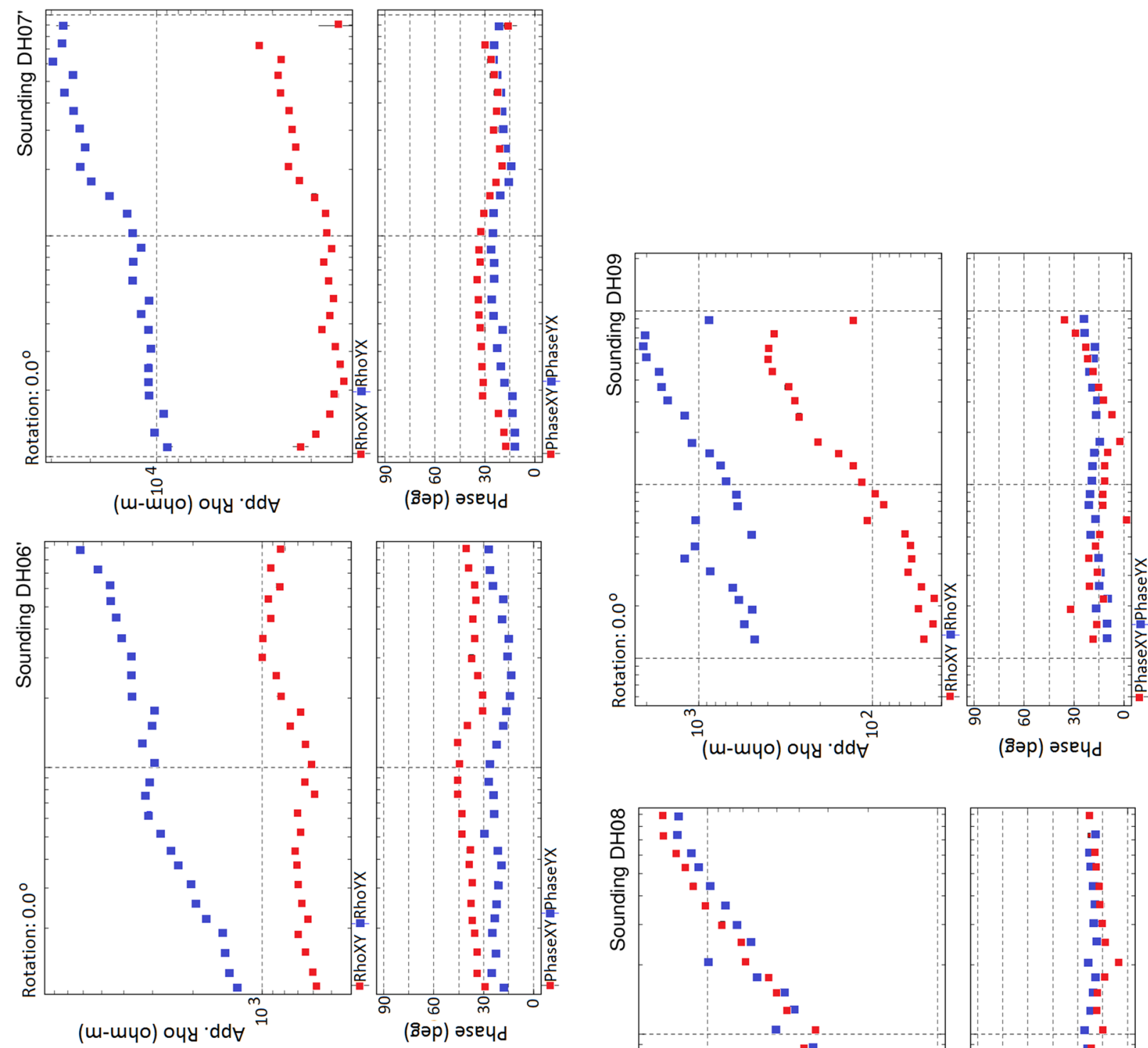

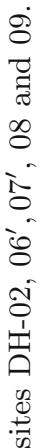
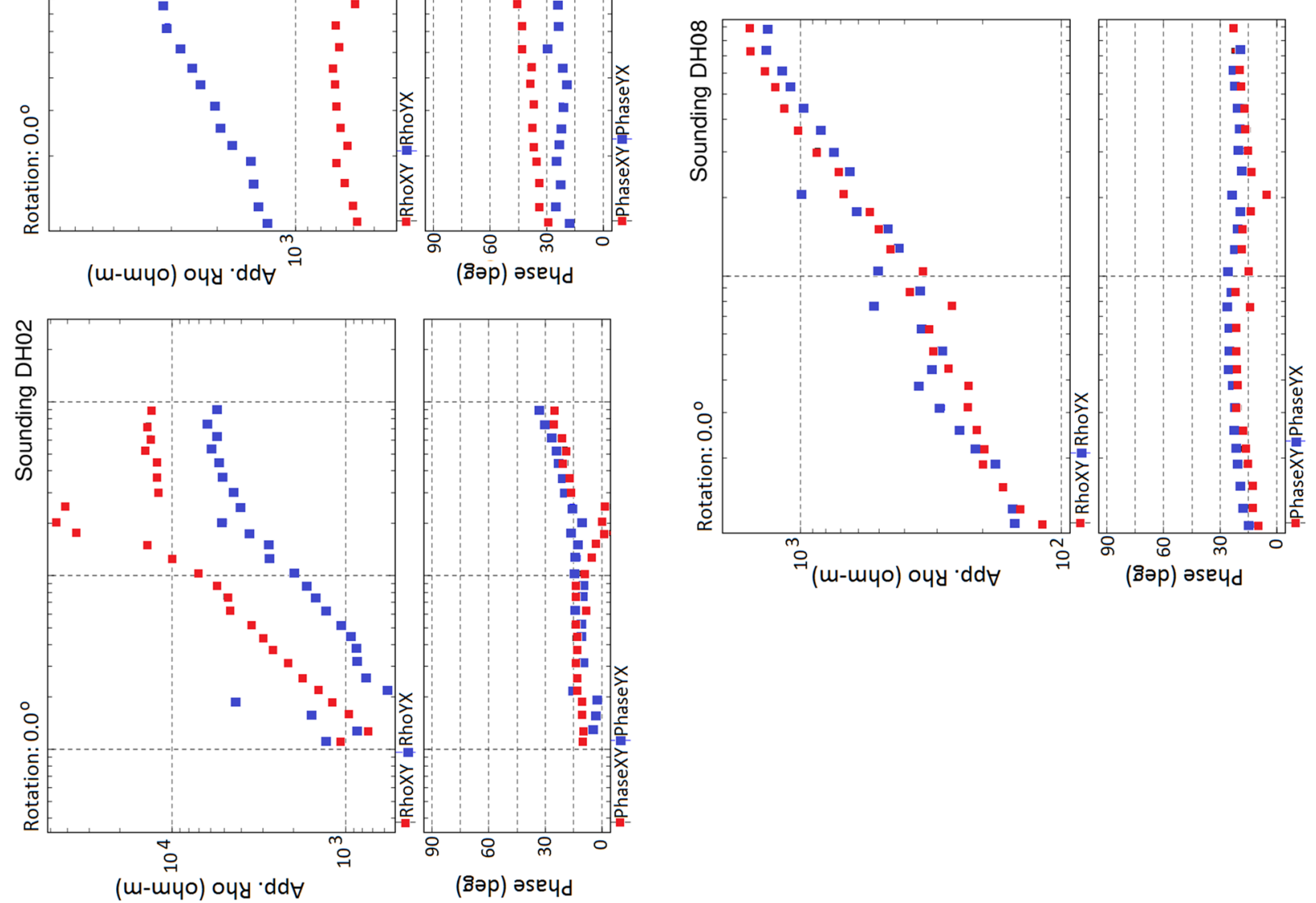

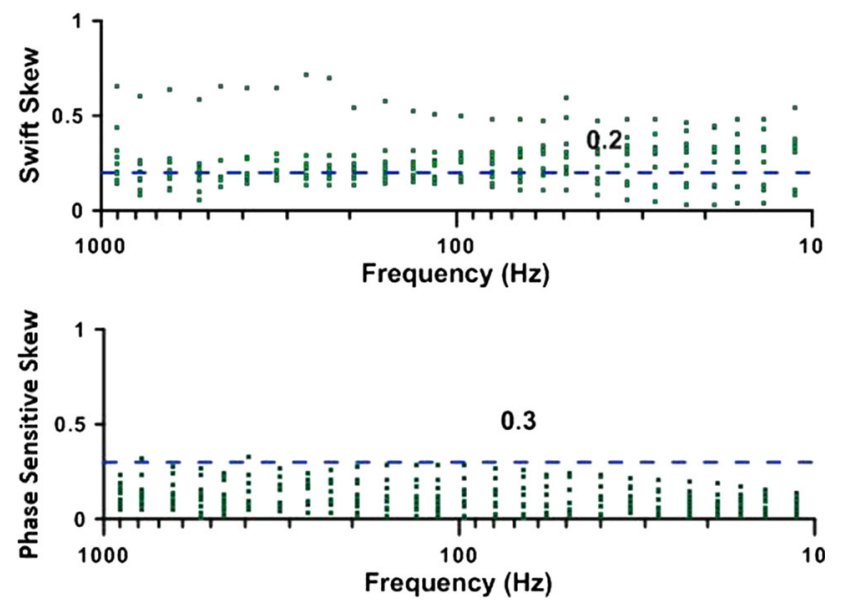

Figure 3. Swift skew and Phase sensitive skew plot for all the sites for $1 \mathrm{kHz}-10 \mathrm{~Hz}$. The threshold value of Swift skew and Phase sensitive skew are 0.2 and 0.3 for $2 \mathrm{D}$ structures, respectively are also shown.

$(0.3086-2 \pi G \rho) h$ where $G$ (gravitational constant) is $6.673 \times 10^{-11} \mathrm{~m}^{3} / \mathrm{kg} / \mathrm{s}^{2}, \rho$ is the density of the Bouguer slab and $h$ is the geoid height. Next, we have used the average crustal density of $2.67 \mathrm{~g} / \mathrm{cm}^{3}$ for anomaly calculation (Verma et al. 1984).

\section{AMT data analysis}

\subsection{Dimensionality analysis}

We analysed dimensionality through Swift Skew (Swift 1967) and Phase sensitive skew (Bahr 1991) (figure 3 top and bottom). The Swift skew values less than 0.2 indicate that the structure is $2 \mathrm{D}$ (Swift 1967). Figure 3 (top) shows that skew is more than 0.2 for some of the sites.

Phase sensitive skew has been used to investigate the dimensionality as the data is of good quality. Figure 3 (bottom) shows that the phase sensitive skew for the dataset is less than 0.3 for all the sites. Phase sensitive skew value greater than 0.3 can be an indication of $3 \mathrm{D}$ effects in the data, while a smaller skew value $(<0.3)$ is a necessary, but not sufficient, requirement for the impedance data to be considered 2D (Bahr 1991). Thus, a directionality analysis was needed to be carried out to understand the persistent geometry of the study area.

\subsection{Directionality analysis}

Figure 1 (inset rose diagrams) shows the Phase sensitive strike (PSS) for entire AMT frequencies $(1 \mathrm{kHz}-10 \mathrm{~Hz})$ over $\mathrm{DhV}$ and $\mathrm{KG}$ domains. It shows a regional strike of $\sim \mathrm{N} 30^{\circ} \mathrm{W}$ for Dhanjori Group and two different strike directions $\left(\mathrm{N} 30^{\circ} \mathrm{W}\right.$ and $\mathrm{N} 45^{\circ} \mathrm{E}$ ) for Kolhan group. We further looked into the PSS for two frequency bands of both DhV and KG domains (figure $4 \mathrm{a}$ and $\mathrm{b}$ ). It can be seen that for $\mathrm{DhV}$ domain, the strike direction in both the bands are $\mathrm{N} 30^{\circ} \mathrm{W}$ (figure $4 \mathrm{a}$ ). However, $\mathrm{KG}$ domain shows two different strikes for both the frequency bands (figure $4 \mathrm{~b}$ ). For frequency band $1 \mathrm{kHz}$ to $100 \mathrm{~Hz}$, the strike is $\sim \mathrm{N} 45^{\circ} \mathrm{E}$ (figure $4 \mathrm{~b}$, left panel) and for frequency band $100-10 \mathrm{~Hz}$ is $\sim \mathrm{N} 30^{\circ} \mathrm{W}$ (figure $4 \mathrm{~b}$, right panel). The strike direction of $\mathrm{N} 45^{\circ} \mathrm{E}$ for higher frequencies correlates well with the geological trend of $\mathrm{KG}$.

\subsection{Data consistency}

Following the dimensionality and directionality analysis, sites over $\mathrm{DhV}$ for frequencies between 1 $\mathrm{kHz}$ and $10 \mathrm{~Hz}$ and sites over KG for frequencies $100-10 \mathrm{~Hz}$ were rotated in regional strike of $\mathrm{N} 30^{\circ} \mathrm{W}$ and data for higher frequencies between $1 \mathrm{kHz}$ and $100 \mathrm{~Hz}$ of $\mathrm{KG}$ was rotated to the geoelectric strike of $\mathrm{N} 45^{\circ} \mathrm{E}$. AMT impedances can be decomposed into two off-diagonal components across the regional strike called as transverse electric (TE) and transverse magnetic (TM) modes. TE and TM modes describe currents flowing parallel and perpendicular to the strike direction respectively. In rotated AMT data, xy and yx components of apparent resistivity and phases are converted to TE and TM mode responses. We also rotated tipper data of both DhV and KG domains consistent with the strike determined from directionality analysis (figure 4a and 4b). Subsequently, Sutarno phase consistent algorithm (Sutarno and Vozoff 1991) has been used to check the internal consistency. The data is mostly internally consistent as apparent resistivity curves predicted by the phase curves follow the similar trend. The smoothing of the dataset has been carried out using $\mathrm{D}+$ algorithm (Beamish and Travassos 1992). The procedure is valid for most $2 \mathrm{D}$ data and for some $3 \mathrm{D}$ cases and provides a much improved, homogenous and consistent dataset for most of the cases (Beamish and Travassos 1992). The errors attributed to the data for consistency check of MT curves is 5\% both for apparent resistivity and phase data. The smooth D+MT curves follow the trend similar to the field data indicating that the acquired data are internally consistent. 

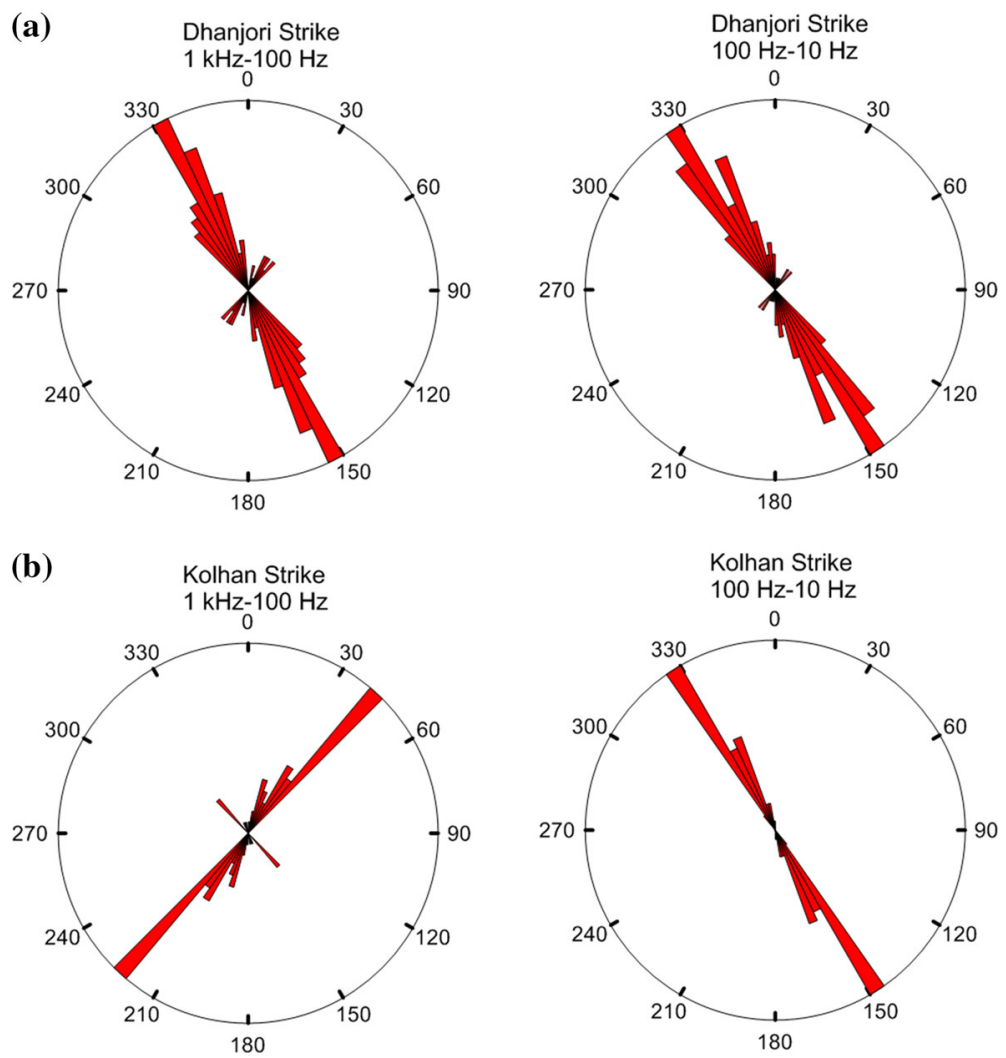

Figure 4. Rose diagrams showing phase sensitive strike direction for frequency ranges $1 \mathrm{kHz}-100 \mathrm{~Hz}$ and $100-10 \mathrm{~Hz}$ : (a) Dhanjori Volcanics; (b) Kolhan Group.

\subsection{Data features}

Prior to modeling of rotated AMT data, the major features were qualitatively evaluated by examining the resistivity and phase curves of both Transverse Electric (TE) and Transverse Magnetic (TM) modes for the representative sites, DH-02, $06^{\prime}, 07^{\prime}$, 08, and 09 (figure 5). DH-08 and DH-09 fall over $\mathrm{KG}$, so while comparing the data feature sites with $\mathrm{DhV}$, we have considered only the frequencies between 100 and $10 \mathrm{~Hz}$, where the strike is similar to DhV (figure 5 top). TM mode apparent resistivity curves for all representative sites for regional profile (figure 5 top) are more than 5000 $\Omega-\mathrm{m}$ at $10 \mathrm{~Hz}$ depicting a resistive basement. TE and TM mode apparent resistivity for site DH-02 lies between 1000 and 10,000 $\Omega$-m with small phase variation between $10^{\circ}$ and $30^{\circ}$ indicating towards uniform resistive basement beneath DhV. Both TM and TE curves show a depression at $100 \mathrm{~Hz}$ for DH-06' indicating that unlike $\mathrm{DhV}$ the basement underneath Quartz Pebble Conglomerate Dhanjori (QPCD) is not uniformly resistive. In fact, DH-06' lies at the boundary of QPCD and PGAU. For DH-08, a representative site of KG, TM appar- ent resistivity curve increases uniformly up to $5000 \Omega-\mathrm{m}$, whereas TE increases up to $200 \Omega-\mathrm{m}$. However, a small variation in phase data between $10^{\circ}$ and $30^{\circ}$ is observed for both $\mathrm{TM}$ and $\mathrm{TE}$ curves indicating towards resistive basement at deeper levels. TM apparent resistivity curve for DH-09 a site over PGAU group shows trend similar to TM apparent resistivity curve of DH-08. Though, the trend for TE apparent resistivity curve for site DH-09 is similar to that of $\mathrm{DH}-$ 08, but lower by one order. TM phases for site DH-09 lies mostly below $20^{\circ}$ whereas TE phases increase up to $50^{\circ}$ for frequencies up to $100 \mathrm{~Hz}$ and then reduces to $\sim 30^{\circ}$ for lower frequencies indicating towards shallow conducting heterogeneities. Splitting in phase data is very small for the site DH-02 within DhV as compared to DH-06' and 09, which are close to lithological boundaries of the study area. TE phase bump is also observed for AMT site DH-06' similar in nature to TE curve depression.

In addition, we also compare the two representative sites, DH- $07^{\prime}$ and 09 of KG domain for frequencies between $1 \mathrm{kHz}$ and $100 \mathrm{~Hz}$. For DH-07' both TE and TM modes depict higher apparent 


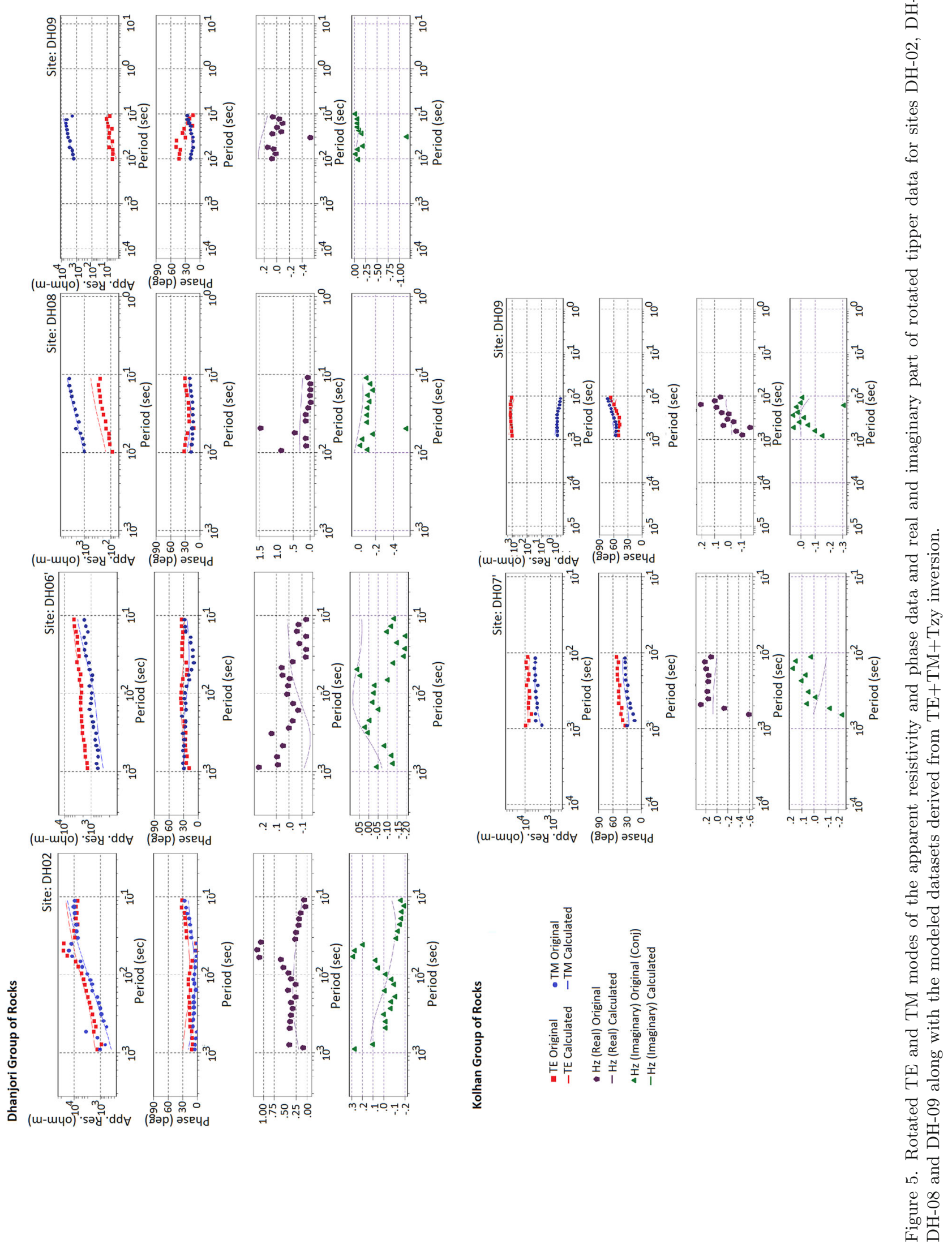


resistivity varying between 2000 and 10,000 $\Omega-\mathrm{m}$. However, TE phases are relatively high in comparison to $\mathrm{TM}$ phases for $\mathrm{DH}-07^{\prime}$ with significant phase splitting. For DH-09 over PGAU, both TE and TM mode apparent resistivity curves are separated with large difference. These sites have significantly high TE and TM phases. Large split in TE and TM apparent resistivity curves along with large phases for higher frequencies may be due to the presence of local scale conducting heterogeneities below site DH-09.

\section{AMT data modeling}

The depth of maximum eddy current flow (Weidelt 1972) or depth of investigation (Spies 1989) related to skin depth helps in determining the depth within which the anomalies could be resolved. The average resistivity from both TE and TM curves is 500 $\Omega-\mathrm{m}$ and $5000 \Omega-\mathrm{m}$ at $1 \mathrm{kHz}$ and $10 \mathrm{~Hz}$ respectively. The corresponding EM skin depths are $350 \mathrm{~m}$ and $11,250 \mathrm{~m}$. Thus, the depth of investigation, which is one-third to two-third of skin depth, for the study area lies between 110 and $240 \mathrm{~m}$ for $1 \mathrm{kHz}$ and $3700-7550 \mathrm{~m}$ for $10 \mathrm{~Hz}$ and accordingly the model features from $200 \mathrm{~m}$ to $4 \mathrm{~km}$ are discussed.

An overview of geometry suggests 2-D features both over Dhanjori for frequencies in between $1 \mathrm{kHz}$ and $10 \mathrm{~Hz}$ and $\mathrm{KG}$ for frequencies 100 and $10 \mathrm{~Hz}$ with a geoelectrical strike of $\sim \mathrm{N} 30^{\circ} \mathrm{W}$. In addition, frequencies above $100 \mathrm{~Hz}$ for KG depict geoelectric strike of $\sim \mathrm{N} 45^{\circ} \mathrm{E}$, consistent with its geological trend. Inversion was performed for regional profile as well as for KG domain. While performing inversion for regional profile, we considered the frequency range of $1 \mathrm{kHz}$ to $10 \mathrm{~Hz}$ for sites over $\mathrm{DhV}$ and $100-10 \mathrm{~Hz}$ for sites over KG as the strike direction is same in these bands. First, TE and TM modes apparent resistivity, phases and rotated tipper for Dhanjori and KG domain sites having regional strike of $\sim \mathrm{N} 30^{\circ} \mathrm{W}$ were inverted using 2-D non-linear conjugate gradient (NLCG) algorithm of Rodi and Mackie (2001) along a profile with an orientation of $\mathrm{N} 60^{\circ} \mathrm{E}$ orthogonal to regional strike (figure 6 ). This $2-\mathrm{D}$ model domain was discretized into 29 rows and 101 columns. Initial mesh size in X- and Z-directions is one-half and one-tenth of skin depth, respectively representing the width of station columns and first layer thickness. The horizontal and vertical widths of the mesh cells were increased by a factor of 1.5 and 1.2 , respectively with initial mesh size of $\sim 83 \mathrm{~m}$ and $\sim 17 \mathrm{~m}$, respectively. The horizontal factor in 2 $\mathrm{D}$ models controls the increment in the width of horizontal cells after station columns. Thus, horizontal cell size increases when we move away from station. It signifies the AMT lateral resolution limits embedded in data. As initial mesh size in $\mathrm{X}-$, direction below stations is 0.5 of skin depth and AMT lateral resolution limit is two to three times of skin depth. The difference between onehalf of initial mesh size in X-direction and MT resolution limit, i.e., $1.75-2.75$ defines the next adjacent cell horizontal dimension appropriately. Thus, a factor of 1.5 is preferred to provide cell size increment in X-direction. The inversions were carried out with different uniform half-space resistivity varying from 100 to $10 \Omega-\mathrm{m}$. The inversion results did not show any significant variation in the obtained model features for uniform half-space resistivity less than $50 \Omega-\mathrm{m}$. Thus, the inversion results discussed here obtained using a uniform half-space of resistivity $50 \Omega-\mathrm{m}$. In the NLCG inversion, the smoothness of the model is controlled by the regularization parameter tau. With the increase of tau, the model becomes smoother at the cost of higher RMS. Figure 7 shows the variation of normalized roughness with RMS for tau varying from 0.01 to 100 . The nature of the curve is L-shape. The corner of the L-curve gives an idea of the optimum value of tau. Figure 7 shows large normalized roughness at low tau, attributed to spatial aliasing with more rough small-scale structures. Figure 7 indicates preferred tau varying from 0.1 to 3.0. Using lower tau values will result in some unwanted structures present between the stations. Thus, we have chosen tau as 1.0 for inversion.

Figure 2, particularly for site DH-02, shows that the apparent resistivity data is affected by static shift phenomenon. Inversion was carried out by increasing the error floor of TE mode apparent resistivity data to tackle the static shift problem. The inversion was attempted with error floors of $20 \%$ for TE mode apparent resistivity, $10 \%$ for TM mode apparent resistivity and TM and TE mode phase and 0.1 for tipper data. Static shift coefficients (figure 6c) estimated by inversion algorithm for the inversion is less than a decade for most sites except for sites DH-01, 03 and 05. The discontinuous line shows a shift of one which represents no static shift (Türkoğlu et al. 2015). It was estimated using a damping factor of 10000 and it damps the inversion in a manner so that no large changes are 


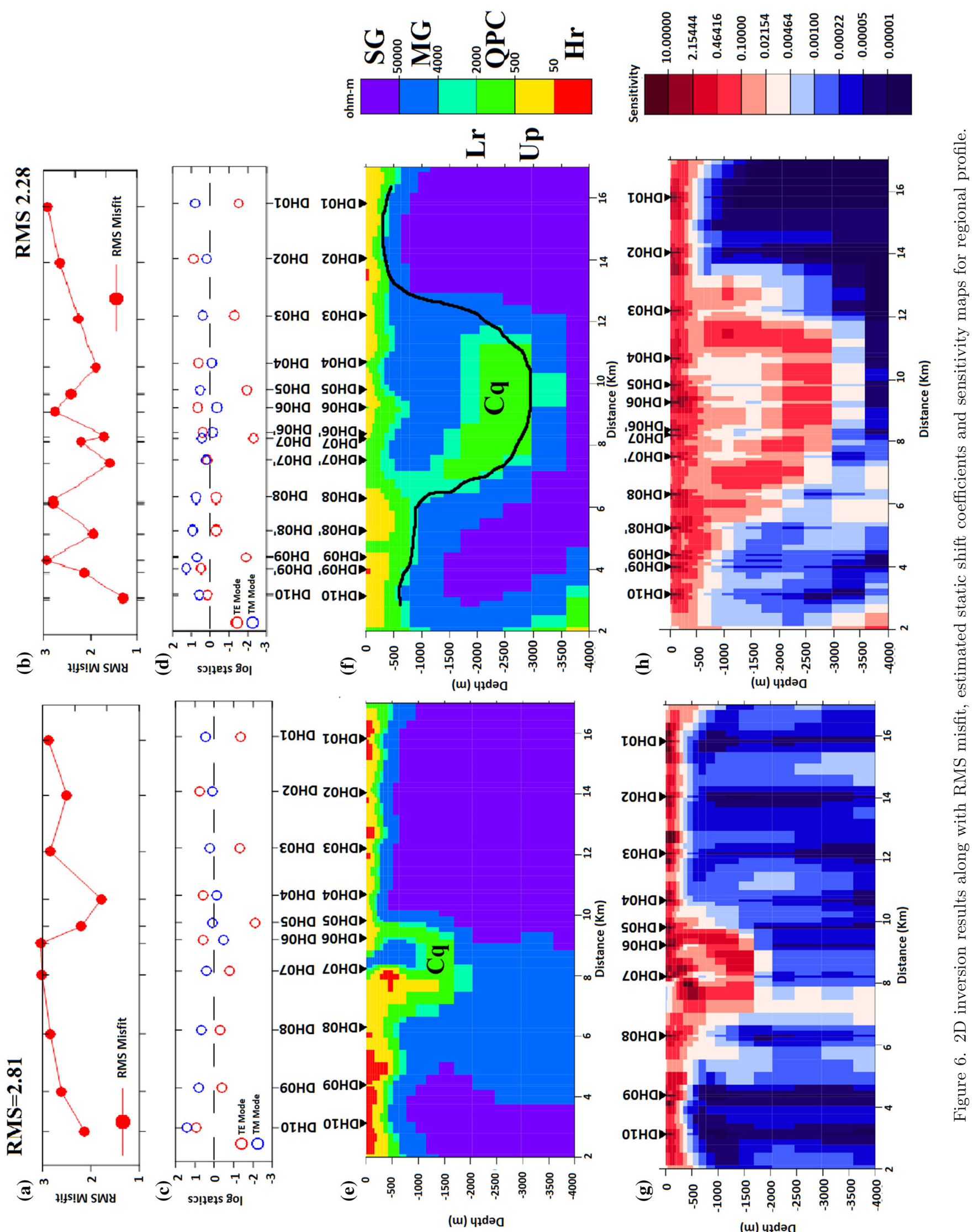


made to static shift coefficients for initial iterations. The inversion scheme tries for good fitting of data prior to applying any changes by static shifts.

TE mode is more sensitive for deep conducting features while TM mode for shallow resistors. However, tipper data provides information on lateral conductivity variation of shallow conducting feature and shows more evidence of complexity related to the area. The inclusion of the tipper data in the inversion can also significantly improve the subsurface resolution (Siripunvaraporn and Egbert 2000; Rodi and Mackie 2001; Tuncer et al. 2006; Siripunvaraporn and Egbert 2009). In view of this, we have inverted TE+TM+Tzy to uncover the geology beneath Dhanjori with more robust and meaningful features. It recovers the electrical structures in complex geological environment substantially with overall RMS of 2.8. The site wise RMS misfit is shown in figure 6(a).

Figure 5 also illustrates the comparison of plots between observed and computed data for representative sites DH-02, $06^{\prime}, 08$ and 09 for regional profile and $\mathrm{DH}-07^{\prime}$ and 09 for $\mathrm{KG}$ domain model. For most of the sites, both apparent resistivity and phase data show a good match except DH-09. DH09 depicts a large mismatch in TE phases for lower frequencies between $100 \mathrm{~Hz}$ and $10 \mathrm{~Hz}$ for regional 2-D model. Site DH-09 also depicts improved fits in both TE and TM phases for higher frequencies between $1 \mathrm{kHz}$ and $100 \mathrm{~Hz}$ for KG domain model. Thus, larger mismatch of TE phases of DH-09 for lower frequencies possibly is related to shallow conducting heterogeneity which is mapped by KG domain model. In fact, Park and Torres-Verdin (1988) also observed larger mismatch in phase data as compared to apparent resistivity data in volcanic environment of Long Valley, California, and attributed this to shallow 3-D structures in the complex geologic environment. Modeled tipper data follows the trend same as that of observed tipper data with few exceptions such as DH-07' where the tipper data seems to be more scattered.

Two-dimensional conductivity model from the regional profile (figure 6e) covering both $\mathrm{KG}$ and DhV domains resolves important geological structures. These structures are Dhanjori group members, i.e., upper member with resistivity between $\sim 50$ and $500 \Omega-\mathrm{m}$ and lower member having resistivity of $\sim 500$ to $4000 \Omega-\mathrm{m}$, Mayubhanj Granite with 4000-50,000 $\Omega-\mathrm{m}$, QPC beds or Phuljhari Formation with 500-2000 $\Omega$-m (Conductor $\mathrm{Cq}$ ) and Singhbhum Granite with more than

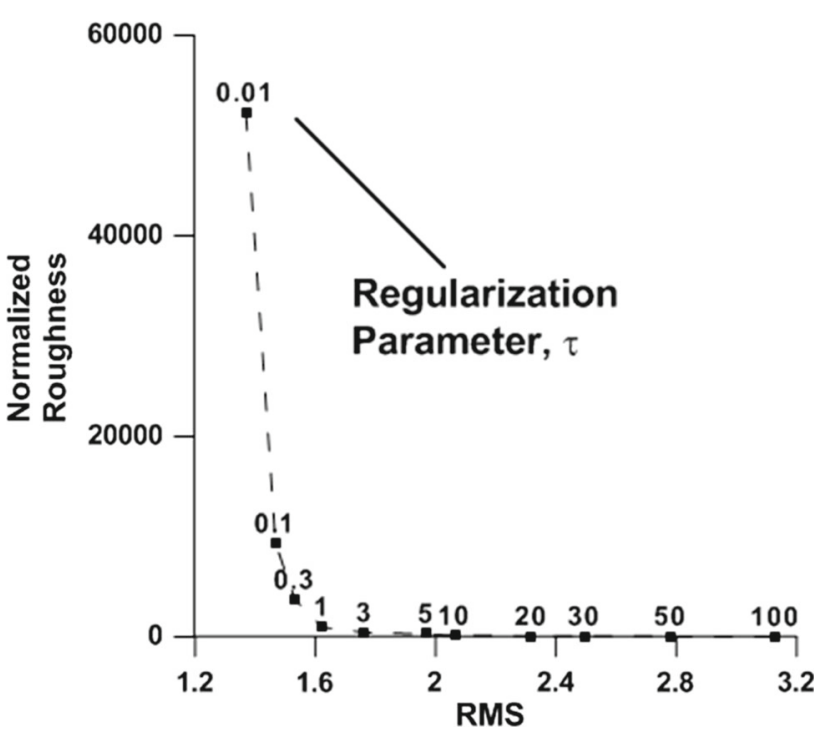

Figure 7. Normalized roughness vs. RMS misfit for different values of tau.

$50,000 \Omega-\mathrm{m}$ resistivity. Two major conducting lithologies, Upper Dhanjori member (50-500 $\Omega$-m) and QPC beds (500-2000 $\Omega-\mathrm{m})$, have distinct resistivity ranges by an order and is clearly distinguishable from their surrounding formations.

We further inverted the regional profile by including four more AMT sites (DH-06 ${ }^{\prime}, 07^{\prime}, 08^{\prime}$ and $\left.09^{\prime}\right)$ for validating the deeper conducting feature $\mathrm{Cq}$ (figure $6 \mathrm{f}$ ). The central portion of figure 6(e) could not resolve the Mayurbhanj Granite and Phuljhari Formation as compared to figure 6(f). In fact, the overall RMS reduced to 2.28 from 2.81. This significant improvement in RMS may be attributed to the development of conductor Cq, related to Phuljhari Formation, overlain by resistive feature of Mayurbhanj Granite. Sitewise RMS reduction is observed for sites DH-03, 06 and 07 due to the inclusion of sites $\mathrm{DH}-06^{\prime}$ and $\mathrm{DH}-$ $07^{\prime}$. The conductor $\mathrm{Cq}$ continues underneath all of these sites almost at the same level (figure 6f). Moreover, conductor $\mathrm{Cq}$ is overlain by Mayurbhanj Granite and continues beneath site DH-07 in KG domain.

Next, we inverted TE+TM+Tzy data for KG domain with four sites (DH-07, 08, 09 and 10) rotated to strike of $\mathrm{N} 45^{\circ} \mathrm{E}$ for higher frequencies between $1 \mathrm{kHz}$ and $100 \mathrm{~Hz}$ along a profile orientation of $\mathrm{N} 45^{\circ} \mathrm{W}$ orthogonal to the strike (figure $8 \mathrm{e}$ ) with an overall RMS of $\sim 1.53$. All inversion parameters were considered same as previous $2-\mathrm{D}$ inversion run (figure 6). As 2-D inversion from KG domain sites samples only higher frequencies up to 
(a)

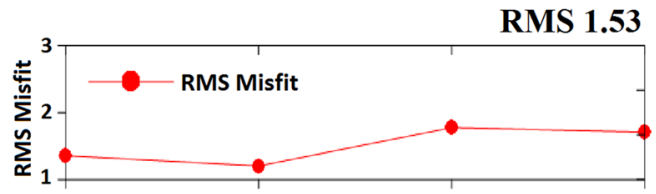

(c)

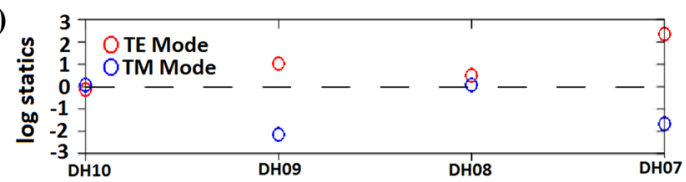

(e)

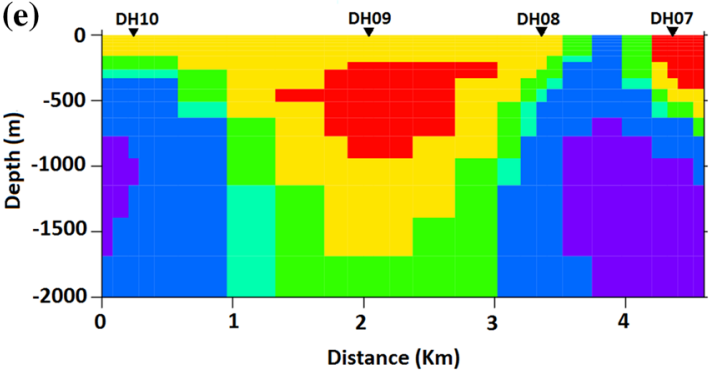

(g)

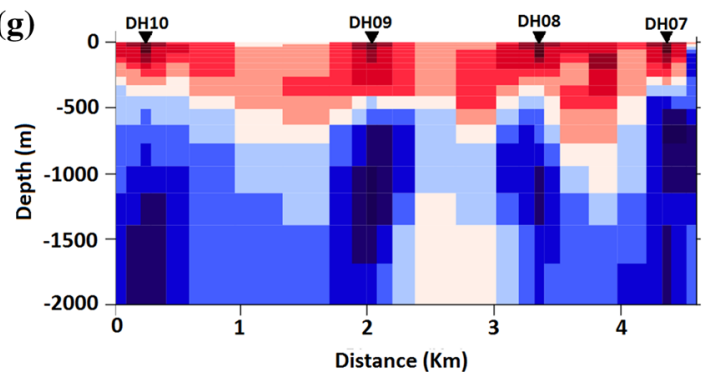

(b)

RMS 1.66

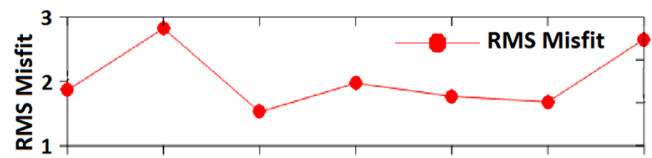

(d)
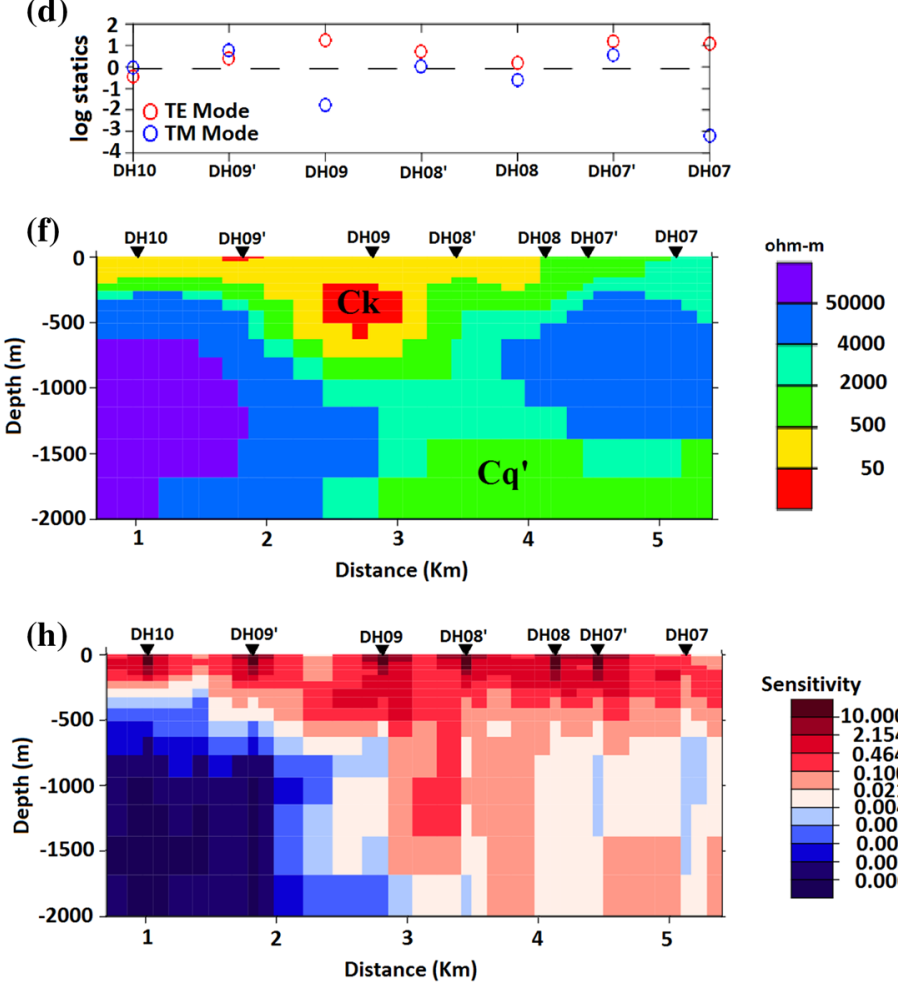

Figure 8. 2D inversion results along with RMS misfit, estimated static shift coefficients and sensitivity maps for KG domain profile.

$100 \mathrm{~Hz}$, thus, lacks lateral resolution limits with larger station spacing of $\sim 2 \mathrm{~km}$ and incites for spatial aliasing problems for KG domain sites as most of the structures are site biased (figure 8e). In view of the above, we included three more AMT sites (DH-07',08 and $\left.09^{\prime}\right)$ for 2-D inversion of KG domain to map the features biased spatially through under-sampling between two adjacent sites (figure 6f). Inclusion of these sites increases the overall RMS marginally from 1.53 to 1.66. On comparison of RMS misfit site-wise for seven sites to four sites KG model (figure 8a and b), there is a marginal increase in RMS for sites DH-07 and DH-10, while sites DH-08 and DH-09 there is a reduction in RMS. The obtained model features are same except for sites DH-07 and 09 (figure 8e and f) which may be due to the presence of conductive and resistive features below these sites. Both the conducting features $\mathrm{Ck}$ and $\mathrm{Cq}^{\prime}$ are located at the boundary between PGAU-KG and KG-QPCD respectively. Conductor $\mathrm{Cq}^{\prime}$ has a lateral eastward extension of the conductor $\mathrm{Cq}$ (figure 6e). Both the conductors $\mathrm{Cq}$ and $\mathrm{Cq}^{\prime}$ can be interpreted as Phuljhari Formation overlain by a younger Mayurbhanj Granite, which is consistent in both the models (figures 6 and 8) favouring for the 2-D inversion of KG domain with seven sites. Both regional (figure 6f) and KG domain (figure 8f) 2-D models show common linked concordant features, explaining the consistency of the 2-D results.

The robustness of the model features (figures $6 \mathrm{f}$ and $8 \mathrm{f}$ ) were analyzed by carrying out the sensitivity tests (figures $6 \mathrm{~h}$ and $8 \mathrm{~h}$ ). The low sensitivity demonstrates that these zones are insensitive to perturbations of cell and the RMS misfit of the model will not change drastically. Further, it illustrates that the conducting shallow features of $<500 \Omega-\mathrm{m}$ are sensitive and may be attributed to shallow conducting heterogeneities in all the obtained models. The resistive features enveloping these conductors are moderately sensitive. The resistors of $>4000 \Omega-\mathrm{m}$ resistivity are mostly insensitive. 
Regional profile AMT models sensitivity maps with 14 (figure 6h) and 10 sites (figure 6g) show most consistent robust features almost along the entire profile except for central part. Shallow conducting features are mostly sensitive and deep resistive features are mostly insensitive in both the sensitivity maps and is more evident in figure 6(h). Central part depicts sensitive conducting feature $\mathrm{Cq}$ at different levels in both the maps. Resistive feature overlain by the deep conducting feature seems insensitive in the sensitivity map (figure $5 \mathrm{~h}$ ).

KG domain models sensitivity maps with seven (figure $8 \mathrm{~h}$ ) and four sites (figure 8g) demonstrate the need for inclusion of more AMT sites. Conductor $\mathrm{Cq}^{\prime}$ is relatively deep and insensitive in the model with more AMT sites (figure 8h) and is consistent with regional profile conductor $\mathrm{Cq}$ (figure 6h). However, shallow conductor $\mathrm{Ck}$ depicts high sensitivity in both the models of $\mathrm{KG}$ domain which changes its dimension in both the models with the same location.

Accordingly, sensitivity analysis has been performed for both the conductors $\mathrm{Ck}$ and $\mathrm{Cq}$ by varying its dimension and resistivity (Thiel and Heinson 2010). We performed sensitivity analysis for the conductors $\mathrm{Ck}$ (figure 8f) and $\mathrm{Cq}$ (figure 6f) from 2-D models as these conductors have quite sensitive features in the obtained sensitivity maps (figures $8 \mathrm{~h}$ and $6 \mathrm{~h}$ ). Resistivity of the conductor Cq (figure $6 \mathrm{~h}$ ) $\sim 1458 \Omega$-m was replaced by one order higher resistivity of $\sim 3162 \Omega-\mathrm{m}$. Inversion was performed by considering this as an initial model with final RMS reducing to 2.28 from 2.29. Secondly, we replaced $\mathrm{Cq}$ with one order lower resistivity of $\sim 355 \Omega$-m, the inversion was performed with this as the initial model, the final RMS remains 2.28 same after inversion. Thus, replacing conductor with one order higher and lower resistivity values does not affect the final RMS with repeated inversion, proves the robustness of the obtained conductor Cq from the regional 2-D model. Similar sensitivity analysis was carried out for conductor Ck (figure 6f) by replacing its true resistivity of $\sim 35 \Omega$-m up to three orders higher resistivity values, i.e., 355, 1458, 3162 and 35,468. After inversion the obtained final RMS were 1.67, 1.66, 1.66 and 1.66 respectively as compared to 1.66 . Final 2-D model in each case always found most similar structures and also converges to same RMS misfit. Thus, both the conducting features, i.e., $\mathrm{Ck}$ of $\mathrm{KG}$ domain model and $\mathrm{Cq}$ from regional model, are robust features obtained from 2-D inversion.

\section{Results and discussion}

Haque and Dutta (1996) showed the presence of gold with significant amount of uranium in the pyritiferous QPCD - also recognised as paleoplacers, group of rocks within the Dhanjori basin of eastern Singhbhum region. It occurs as interbedded sequence within the quartzite phyllites package belonging to the Lower Proterozoic Dhanjori Group of rocks. QPCDs form extended lensoidal bodies/bands along the axis of extension. The dominant mineral constituent of QPCD is quartz occurring both as clastic grains as well as in matrix possibly making it less conducting in comparison to massive sulfides. Granite-Greenstone belt of the Singhbhum Craton appears to have constituted the provenance. Possibly, the QPCD is a product of alluvial fan deposit of braided river system. The common ore mineral is pyrite, some of which are altered to goethite and limonite. The matrix sometimes also has chalcopyrite and pyrrhotite which occurs as inclusions within the other minerals.

All along the regional profile up to a maximum depth of $\sim 500 \mathrm{~m}$, the presence of Upper $\mathrm{DhV}$ is observed (figure 5f). The conductors, $\mathrm{Ck}$ within $\mathrm{KG}$ domain and $\mathrm{Cq}$ within $\mathrm{DhV}$ are interpreted as some sulfide body which may host gold and are horizontally disposed due to the Mayurbhanj Granite intrusives corresponding to resistivity of 4000-50,000 $\Omega-\mathrm{m}$.

The thickness of DhV varies laterally with maximum $(\sim 3 \mathrm{~km})$ (figure $6 \mathrm{~h}$ thick black line) at the centre of the DhV and shallows up towards PGAU of rocks in the west and $\mathrm{DhV}$ in the east. Thus, a high resistive signature is observed over granitic basement and intrusive and low resistivity over QPCD associated rocks within Dhanjori Greenstone belt. The results are similar to those of superior province of the Precambrian shield in northwestern Ontario, Canada (Koziar and Strangway 1978).

Figure 9 (top) shows variation of gravity residual anomaly. A prominent gravity high is observed over Protetozoic Gabbro Anorthesite Ultramafics (PGAU) and two relatively small gravity high values are observed over DhV. The modelling of the residual anomaly is carried out by considering three main geological domains, viz., DhV, PGAU and Singhbhum/Mayurbhanj Granite group of rocks, over the study area. The density values used for modeling for DhV, PGAU and Singhbhum/ Mayurbhanj Granite are 3.05, 3.01 and 2.68 g/cc, 

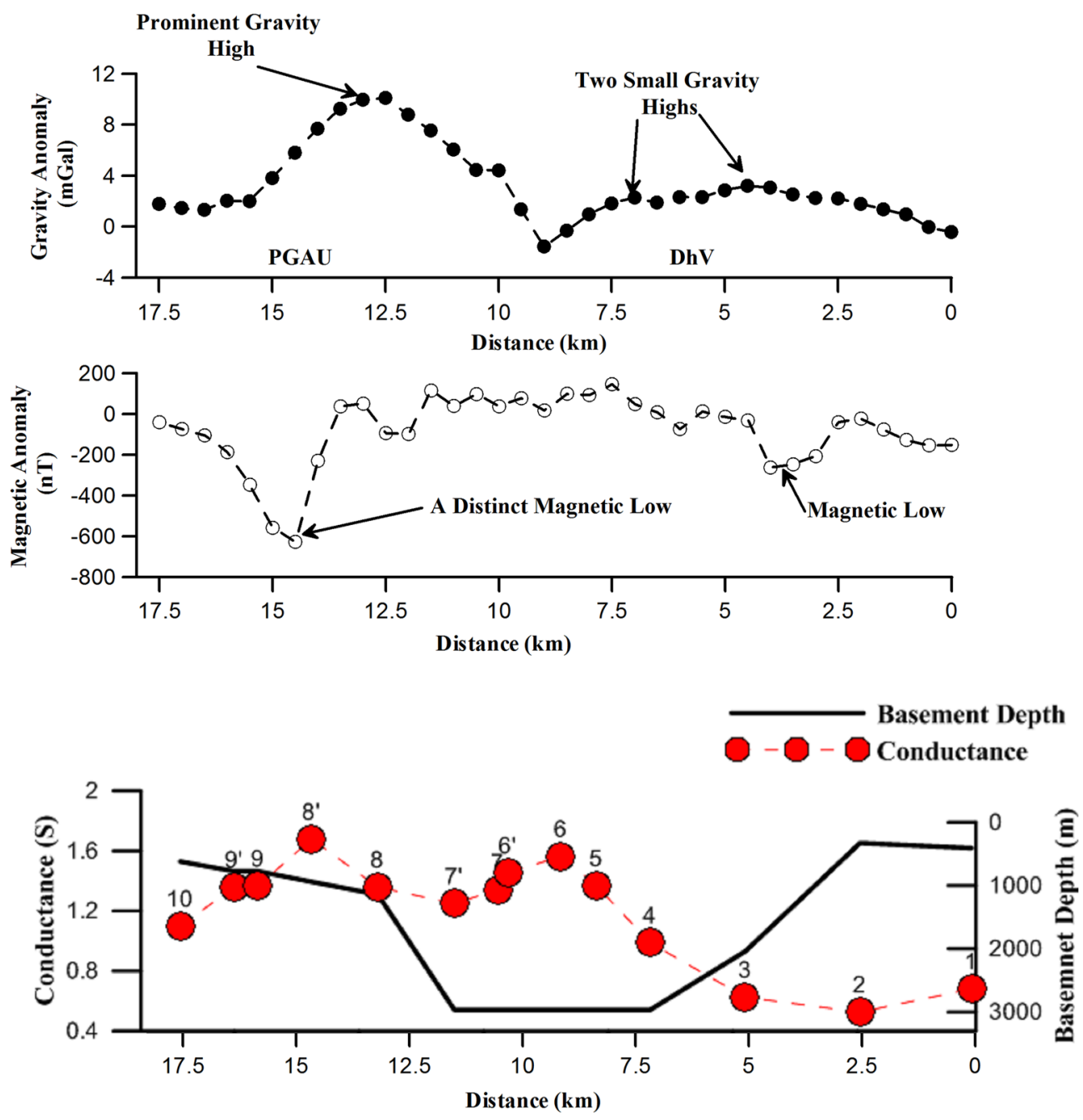

Figure 9. Top: gravity (mGals); middle: magnetic (nT) residual anomalies along a profile parallel to AMT transect, and bottom: conductance and basement depth obtained from regional profile (figure 6h) vs. distance.

respectively. These have been adapted from Verma et al. (1984). The observed and modeled residual gravity anomaly, with an error of 0.40 , along with the model is shown in figure 10. The southwestern and central parts of the profile are over the $\mathrm{DhV}$, whereas the northeastern end of the profile is over gabbro-anorthosite. Gravity high of +10 mgal in the northeastern part is attributed to gabbro-anorthosite whereas the gravity high in the central and southwestern parts of +3 mgal is attributed to $\mathrm{DhV}$. The difference of about +7 mgal as compared to northeastern and central and southwestern profile is due to the absence of gabbro-anorthosite group of rocks in the central and southwestern parts. In the central part of the profile, the volcanics is having maximum thickness. The thickness of the base of Dhanjori basin is around $3.00 \mathrm{~km}$ as compared to $2.75 \mathrm{~km}$ of Verma et al. (1984). The thickness reduces in the southwestern part of the profile due to lesser thickness of the volcanic and gabbro-anorthosite mass.

A distinct magnetic low (figure 9, middle) is also observed over PGAU and a relatively small magnetic low is also seen over the Dhanjori Group of rocks. The prominent gravity high and distinct magnetic low over PGAU group of rocks is coinciding with each other showing the presence of high density and low susceptibility rocks underneath it. This along with conductivity signatures signifies the presence of some sort of sulfidic mineralization enriched with gold.

We deduced the conductance variation (figure 9, bottom) from regional 2-D model (figure 6h) up to basement depth to compare it with gravity and magnetic anomalies (figure 9, top and middle). Towards west and central parts of the profile, the estimated conductance depicts two highs for both 

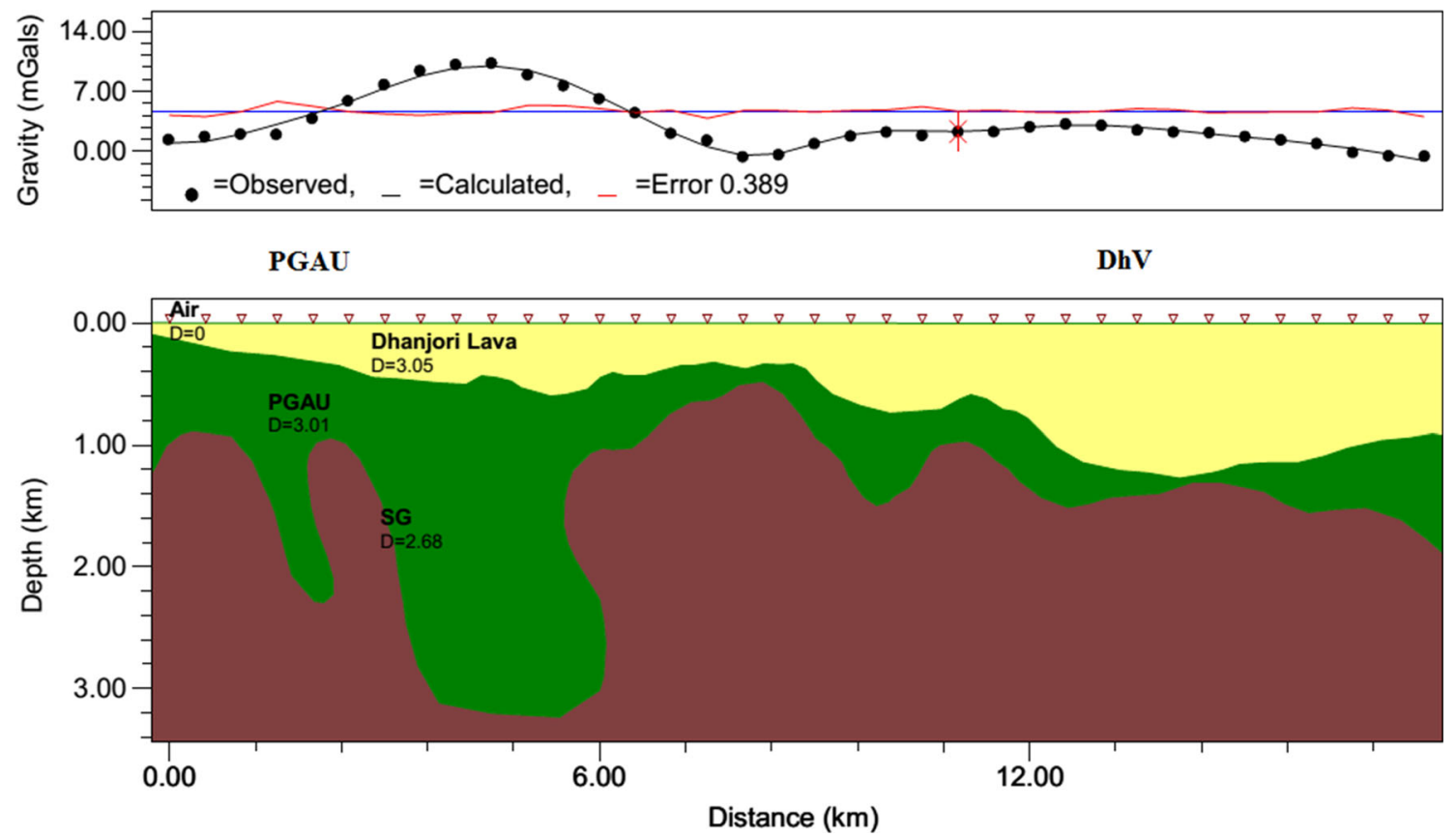

Figure 10. Observed and computed residual gravity anomaly (top) and gravity model (bottom) along same profile parallel to AMT transect. The average density for Dhanjori Volcanics, Gabbro Anorthesite Ultramafics and Singhbhum/Mayurbhanj Granites are 3.05, 3.01 and 2.68, respectively.

the delineated conductors related to conductors $\mathrm{Ck}$ and $\mathrm{Cq}$, below KG group and QPC beds respectively. These coincide with regional gravity highs and magnetic lows (figure 9, top and middle). However, shallow granitic basement attributed to low conductance values towards east end of the profile.

Terrestrial heat flow of $\sim 61 \mathrm{~mW} / \mathrm{m}^{2}$ along with a high geothermal gradient of $\sim 20^{\circ} \mathrm{C} / \mathrm{km}$ was reported in Mosabani mine (figure 1) located in a thrust zone lying at the north eastern margin of the DhV (Verma et al. 1966). Mazumder et al. (2000) reported a $15-20 \mathrm{~km}$ thickness of the crust below the DhV from Rb-Sr distribution and silica normalized $\mathrm{K}_{2} \mathrm{O}$ content. These observations infer thinning of crust beneath DhV. DhV formed due to intra-continental rift setting suggested from interbedded terrestrial deposits (Eriksson et al. 1999; Mazumder and Sarkar 2004). The existence of the Dhanjori basalts including komatiites and komatiitic basalts within upper members of $\mathrm{DhV}$ implies subsequent upwelling of mantle plume and decompression melting following crustal extension (Mazumder and Sarkar 2004). Thus, crustal extension and extensive crustal thinning beneath the DhV along with high geothermal gradient and rifted margin gives rise to metallogeny in the form of rifted phase greenstone belts with gold enriched sulfide mineralization.
The conductivity model indicated the presence of shallow conductors, but could not be resolved due to lack of high frequency data. However, the results from the close-by drill site indicate the presence of shallow conductors. The borehole BH TA-2 (figure 1) drilled by GSI (Das et al. 2008) is located about an offset of $\sim 2.0 \mathrm{~km}$ from DH-03 (figure 1). Borehole depicts three major lithologies, i.e., metabasalts, tuffs and foliated meta-basalts, associated with different concentrations $(0.5-2.0 \%)$ of sulfide mineralization up to depth of about $300 \mathrm{~m}$. In general, conductors can be related to sulfide body associated with pyrite which may host gold. Moderately resistive feature may represent basalt and meta-basalt and also with successive bands of sulfides. The chargeability and density values of a few selected drill core samples drawn from different horizons vary from 10 to $30 \mathrm{mV} / \mathrm{V}$ and 2.4 to $3.6 \mathrm{gm} / \mathrm{cc}$, respectively (Das et al. 2008). They interpreted a high density with high chargeability and low resistivity features as sulfide bodies. These conductors are enveloped in the relatively less sulfidic host rocks related to the Dhanjori meta-sediments. The Dhanjori Group of rocks act as a main formation which envelopes host rocks of sulfide mineralization. The moderate resistors of resistivity 2000-4000 $\Omega-\mathrm{m}$ are associated with the $\mathrm{DhV}$. The highly resistive basement rock is associated with the lithology of Singhbhum Granite. 
The rock samples from the $\mathrm{DhV}$ have been studied to determine the concentration of gold, silver, copper, uranium, magnetite, lead and zinc. Inductively Coupled Plasma Atomic Emission Spectroscopy (ICP-AES) analysis was carried out on the samples collected from the Dhanjori group of rocks. The analysis indicates an average value of gold, silver, copper, uranium, magnetite, lead and zinc are $5 \mathrm{ppm}$, trace, $110 \mathrm{ppm}, 50 \mathrm{ppm}, 1.5 \mathrm{ppm}$, $6.5 \mathrm{ppm}$ and $55 \mathrm{ppm}$ respectively. The concentration of gold mineralization is $\sim 5.0 \mathrm{~g} / \mathrm{t}$. The geochemical analysis of systematic channel samples indicated anomalous gold value in approx. $58 \%$ of the QPCDs samples is in the range of 0.05-3.8 ppm (Haque and Dutta 1996).

\section{Conclusions}

We investigated DhV, a rather complex geological paleo-Proterozoic greenstone belt of eastern India through regional AMT, gravity and magnetic surveys.

Geo-electrical structure underneath $\mathrm{DhV}$ is, in general, two-dimensional. Conductivity model obtained from AMT surveys depicts the regional stratigraphy as upper conducting and moderately resistive lower members of Dhanjori Group are underlain by younger resistive Mayurbhanj granite, which is overlying above the moderately conducting Phuljhari Formation. Moreover, basement rocks are mainly representative of highly resistive Singhbhum Granite.

Conductivity model indicates the presence of shallow conductors, but could not be resolved due to lack of high frequencies. Further, two more conducting features one each in KG and QPCD are also observed. Two-dimensional models show common linked concordant features between the regional and $\mathrm{KG}$ profiles, explaining the consistency of the $2-\mathrm{D}$ results. The sensitivity analysis suggests that these conductors are robust.

Gravity signature along the same profile depicts a prominent regional gravity high anomaly which may be attributed to some sort of mineralization. Magnetic signature along the same profile shows a very low distinct magnetic anomaly possibly induced due to deep level gold mineralization of Proterozoic-Archean greenstone belt of DhV. Relatively deep conducting feature belonging to QPC beds is horizontally disposed due to the later intruded younger Mayurbhanj granite. Regional conductivity model resolves the basement structure of Dhanjori basin. It was found that basin is extended up to $\sim 3 \mathrm{~km}$ depth at the central and shallows up both towards Kolhan group of rocks in the west and Singhbhum Group Metapelites in the east. ICP-AES results of Dhanjori samples show significant concentration of gold $\sim 5.0 \mathrm{~g} / \mathrm{t}$, which is of economic consideration. The location of a private gold mining company lies very close to southwestern end of the investigated profile.

\section{Acknowledgements}

SS conveys his sincere thanks to ISM, Dhanbad for providing all the supports to carry out this work. Authors are also thankful to UGC-CAS and DSTFIST for providing financial assistance to complete this work.

\section{References}

Anand S P and Rajaram M 2006 Aeromagnetic data analysis for the identification of concealed uranium deposits: A case history from Singhbhum uranium province, India; EPS 58 1099-1103.

Acharya S K, Gupta A and Orihashi Y 2010 NeoarcheanPaleoproterozoic stratigraphy of the Dhanjori basin, Singhbhum Craton, eastern India and recording of a few $\mathrm{U}-\mathrm{Pb}$ zircon dates from its basal part; J. Asian Earth Sci. 39 527-536.

Anhaeusser C R 1976 Archean metallogeny in southern Africa; Econ. Geol. 71 16-43.

Bahr K 1991 Geological noise in magnetotelluric data: A classification of distortion types; Phys. Earth Planet Inter. 66 24-38.

Beamish D and Travassos J M 1992 The use of the $\mathrm{D}+$ solution in magnetotelluric interpretation; J. Appl. Geophys. 29 1-19.

Craven J A, Roberts B J, Hayward N, Stefanescu M and Corriveau M 2013 A magnetotelluric survey and preliminary geophysical inversion and visualization of the NICO IOCG deposit, northwest territories; Geol. Surv. Can. Open File 7465, p. 25, https://doi.org/10.4095/292869.

Das L K and Agrawal B N P 2001 The evolution of the Singhbhum Craton, A geophysical perspective; Ind. Mineral. 55 143-170.

Das L K, Dasgupta K K and De M K 2008 Mineral potential of Dhanjori Metavolcanics, East Singhbhum, Jharkhand; Ind. Mineral. 61 193-200.

Das N, Royburman K J, Vatsa U S and Mahurkar YV 1990 Sonakhan Schist Belt: A Precambrian granite-greenstone complex; Geol. Surv. India Spec. Publ. 28 118-132.

De Wit M J, Ashwal L D and Lewis D 1997 Greenstone belts; Clarendon Press, New York, Oxford University Press, Oxford.

Dubé B and Gosselin P 2007 Greenstone-hosted quartzcarbonate vein deposits; In: Mineral deposits of Canada: A 
synthesis of major deposit-types, District Metallogeny, the evolution of geological provinces, and exploration methods (ed.) Goodfellow W D, Geol. Assoc. Canada, Mineral Deposits Division, Spec. Publ. 5 49-73.

Dunn J A and Dey A K 1942 Geology and petrology of Eastern Singhbhum and surrounding areas; Geol. Surv. IndiaMemoir 69.

Eriksson P G, Mazumder R, Sarkar S, Bose P K, Altermann $\mathrm{W}$ vander and Merwe $\mathrm{R} 1999$ The 2.7-2.0 Ga volcano-sedimentary record of Africa, India and Australia: Evidence for global and local changes in sea level and continental freeboard; Precamb. Res. 97 269-302.

Foster R P 1985 Major controls of Archean gold mineralization in Zimbabwe; Trans. Geol. Soc. S. Africa 88 109-133.

Goldfarb R J, Groves D I and Gardoll S 2001 Orogenic gold and geologic time: A global synthesis; Ore Geol. Rev. 18 $1-75$.

Groves D I, Phillips G N, Ho S E, Houstoun S M and Standing C A 1987 Craton-scale distribution of Archean greenstone gold deposits: Predictive capacity of the metamorphic model; Econ. Geol. 82 2045-2058.

Haque M D and Dutta S K 1996 Report on the investigation for gold in Dhanjori basin in East Singbhum District, Bihar, Unpublished Report (Geol. Surv. India).

Heinson G S, Direen N G and Gill R M 2006 Magnetotelluric evidence for a deep-crustal mineralizing system beneath the Olympic Dam iron oxide copper-gold deposit, southern Australia; Geology 34 573-576.

Jayananda M, Peucat J-J, Chardon D, Krishna Rao B and Corfu F 2013 Neoarchean greenstone volcanism, Dharwar craton, Southern India: constraints from SIMS zircon geochronology and Nd isotopes; Precamb. Res. 227 55-76, https://doi.org/10.1016/j.precamres.

Jha V, Singh S and Venkatesh A S 2015 Invisible gold occurrence within the quartz reef pyrite of Babaikundi area, North Singhbhum fold-and-thrust belt, Eastern Indian Shield: Evidence from petrographic, SEM and EPMA studies; Ore Geol. Rev. 65 426-432.

Jones A G and Garcia X 2003 Okak Bay AMT data-set case study: lessons in dimensionality and scale; Geophysics $\mathbf{6 8}$ 70-91, https://doi.org/10.1190/1.1543195.

Kailasam L N 1975 Epeirogenic studies in India with reference to recent vertical movements; Tectonophys. 25 505-521.

Kirk J, Ruiz J, Chesley J, Walshe J and England G 2002 A major archean gold- and crust-forming event in the Kaapvaal Craton, South Africa; Science 297 1856-1858.

Koziar A and Strangway D W 1978 Shallow crustal sounding in the Superior Province by audio frequency magnetotellurics; Can. J. Earth Sci. 15 1701-1711.

Krishnamurthy P, Nagar R K, Bagchi A K and Gupta R K 2004 Geophysical surveys for concealed uranium deposits in the North Singhbhum Mobile Belt in Jharkhand and West Bengal; Explor. Res. Atomic Miner. 15 25-31.

Livelybrooks D, Mareschalt M, Blais E and Smith J T 1996 Magnetotelluric delineation of the Trillabelle massive sulfide body in Sudbury, Ontario; Geophysics 61 971-986.

Maurya V P, Shalivahan, Bhattacharya B B, Adhikari P K and Das L K 2015 Preliminary magnetotelluric results across Dalma Volcanics, Eastern India: Inferences on metallogeny; J. Appl. Geophys. 115 171-182.
Mazumder R, Bose P K and Sarkar S 2000 A commentary on tectono-sedimentary record of the pre-2.0 Ga continental growth of India vis-a-vis a pre-Gondwana Afro-Indian supercontinent; J. Africa Earth Sci. 30 201-217.

Mazumder R and Sarkar S 2004 Sedimentation history of the Palaeoproterozoic Dhanjori Formation, Singhbhum, eastern India; Precamb. Res. 130 269-289.

Mazumder R 2005 Proterozoic sedimentation and volcanism in the Singhbhum crustal province, India and their implications; Sedim. Geol. 176 167-193.

Meju M A 2002 Geoelectromagnetic exploration for natural resources: Models, case studies and challenges; Surv. Geophys. 23 133-205.

Park S K and Torres-Verdin C 1988 A systematic approach to the interpretation of magnetotelluric data in volcanic environments with applications to the quest for magma in long valley, California; J. Geophys. Res. B93 13,265$13,283$.

Percival J A 2007 Geology and metallogeny of the superior province, Canada; In: Mineral deposits of Canada: A Synthesis of Major Deposit-Type (ed.) Goodfellows W D, District Metallogeny, the Evolution of Geological Provinces, and Exploration Methods. Ontario, Geol. Assoc. Canada, Mineral Deposits Division, Spec. Publ. 5 903-928.

Pirajno F 2007 Mantle plumes, associated intra plate tectonomagmatic processes and ore systems; Episodes $\mathbf{3 0}$ 6-19.

Queralt P, Jones A G and Ledo J 2007 Electromagnetic imaging of a complex ore body: 3D forward modeling, sensitivity tests, and down-mine measurements; Geophysics $\mathbf{7 2} 85-95$.

Rodi W and Mackie R L 2001 Nonlinear conjugate gradients algorithm for 2-D magnetotelluric inversion; Geophysics 66 174-187.

Saha A K 1994 Crustal evolution of Singhbhum-North Orissa, eastern India; Geol. Soc. India Memoir 27.

Sahoo P R and Venkatesh A S 2014 'Indicator' carbonaceous phyllite/graphitic schist in the Archean Kundarkocha gold deposit, Singhbhum orogenic belt, eastern India: Implications for gold mineralization vis-a-vis organic matter; $J$. Earth Syst. Sci. 123 1693-1703.

Sengupta D, Kumar R, Singh A K and Prasad R 2001 Radon exhalation and radiometric prospecting on rocks associated with $\mathrm{Cu}-\mathrm{U}$ mineralizations in the Singhbhum shear zone, Bihar; Appl. Radiat. Isot. 55 889-894.

Shalivahan Sinharay R K and Bhattacharya B B 2006 Remote reference magnetotelluric impedance estimation of wideband data using hybrid algorithm; J. Geophys. Res. 111 B11103-B11109.

Siripunvaraporn W and Egbert G 2000 An efficient datasubspace inversion method for 2-D magnetotelluric data; Geophysics 65 791-803.

Siripunvaraporn W and Egbert G 2009 WSINV3DMT: Vertical magnetic field transfer function inversion and parallel implementation; Phys. Earth Planet Inter. 173 317-329.

Spies B R 1989 Depth of investigation in electromagnetic sounding methods; Geophysics 54 872-888.

Sproule R A, Lesher C M, Ayer J A and Thurston P C 2002 Komatiites and komatiitic basalt of the Abitibi greenstone belt: A proposed model for their formation; Precamb. Res. 115 153-186. 
Sutarno D and Vozoff K 1991 Phase-smoothed robust Mestimation of magnetotelluric impedance functions; Geophysics 56 1999-2007.

Swift C M 1967 A magnetotelluric investigation of an electrical conductivity anomaly in the south western United States; PhD Thesis, Massachusetts Institute of Technology.

Tuncer V, Unsworth M J, Siripunvaraporn W and Craven J A 2006 Exploration for unconformity-type uranium deposits with audiomagnetotelluric data: A case study from the McArthur River mine, Saskatchewan, Canada; Geophysics 71 B201-B209.

Türkoğlu E, Unsworth M, Bulut F and Çağlar İ 2015 Crustal structure of the North Anatolian and East Anatolian Fault Systems from magnetotelluric data; Phys. Earth Planet Inter. 241 1-14, https://doi.org/10.1016/j.pepi. 2015.01.003.

Thiel S and Heinson G S 2010 Crustal imaging of a mobile belt using magnetotellurics: An example of the Fowler domain in south Australia; J. Geophys. Res. 115 B06102B06109.

Verma R K, Rao R U M and Gupta M L 1966 Terrestrial heat flow in Mosabani Mine, Singhbhum District, Bihar, India; J. Geophys. Res. 71 4943-4948.

Corresponding editor: M RADHAKRISHNA
Verma R K, Sharma A U S and Mukhopadhyay M 1984 Gravity field over Singhbhum, its relationship to geology and tectonic history; Tectonophys. 106 87-107.

Weidelt P 1972 The inverse problem of geomagnetic induction; Z. Geophys. 38 257-289.

Wyche S, Fiorentini M L, Miller J L and McCuaig T C 2012 Geology and controls on mineralisation in the Eastern Goldfields region, Yilgarn Craton, western Australia; Episodes 35 273-282.

Yamaguchi S, Ogawa Y, Fujita K, Ujihara N, Inokuchi H and Oshiman N 2010 Audio-frequency magnetotelluric imaging of the Hijima fault, Yamasaki fault system, southwest Japan; EPS 62 401-411.

Zhang P, Chouteau M, Mareschal M, Kurtz R and Hubert C 1995 High-frequency magnetotelluric investigation of crustal structure in north-central Abitibi, Quebec, Canada; Geophys. J. Int. 120 406-418.

Zhou T, Goldfarb R J and Phillips G N 2002 Tectonics and distribution of gold deposits in China - An overview; Miner. Depos. 37 249-282, https://doi.org/10. 1007/s00126-001-0237-4. 